\section{Analisis Biaya, Pendapatan dan R/C Ratio Usaha Kayu Trubusan Jati Unggul Nasional di Kebun Percobaan Universitas Nusa Bangsa}

\author{
Iis Anisa Yulia, Zainal Muttaqin, Dewi Fitrianti \\ Universitas Nusa Bangsa \\ Email: anisbid@yahoo.co.id
}

Analysis of Cost, Revenue and R/C Ratio

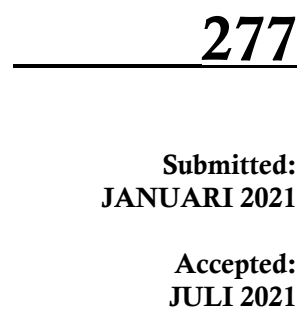

\title{
ABSTRACT
}

This study aims to determine the analysis of costs, income and $R / C$ ratio of the Jati Unggul Nasional business at the Nusa Bangsa University Experimental Garden. The analytical method used is descriptive quantitative method. Quantitative data processing is done by using the calculation of cost and income analysis. This study used secondary data from the management of the Experimental Garden of the University of Nusa Bangsa. The results showed that the costs incurred during the Jati Unggul Nasional business were Rp. 4,105,350, with income from the business is Rp. $278,704,650$. The results also show that the value of the $R / C$ ratio of the Jati Unggul Nasional business is 6.88. The result of the $R / C$ ratio is more than one, so that the Jati Unggul Nasional business is profitable.

Keywords: cost, income, $R / C$ ratio

\begin{abstract}
ABSTRAK
Penelitian ini bertujuan untuk mengetahui analisis biaya, pendapatan dan $\mathrm{R} / \mathrm{C}$ ratio dari usaha kayu trubusan jati unggul nasional di Kebun Percobaan Universitas Nusa Bangsa. Metode analisis yang digunakan adalah metode deskriptif kuantitatif. Pengolahan data secara kuantitatif dilakukan dengan menggunakan perhitungan analisis biaya dan pendapatan. Penelitian ini menggunakan data sekunder yang diperoleh dari pengelola Kebun Percobaan Universitas Nusa Bangsa. Hasil penelitian menunjukkan bahwa biaya yang dikeluarkan selama menjalankan usaha kayu trubusan jati unggul nasional adalah sebesar Rp. 4.105.350. dengan pendapatan dari usaha kayu trubusan jati unggul nasional adalah sebesar Rp. 278.704.650. Hasil penelitian juga menunjukkan bahwa nilai $\mathrm{R} / \mathrm{C}$ ratio dari usaha usaha kayu trubusan jati unggul nasional adalah sebesar 6,88. Hasil R/C ratio tersebut lebih besar dari satu, sehingga usaha kayu trubusan jati unggul nasional yang dilakukan di kebun percobaan UNB menguntungkan.
\end{abstract}

Kata Kunci: Biaya, Pendapatan, R/C Ratio

\section{PENDAHULUAN}

Indonesia memiliki luas wilayah 750 juta hektar (ha) dengan luas daratan sekitar 187.91 juta ha. Berdasarkan hasil pemantauan hutan Indonesia Tahun 2019, menunjukkan bahwa luas lahan berhutan seluruh daratan Indonesia adalah 94,1 juta ha atau $50,1 \%$ dari total daratan. Hutan memiliki beberapa manfaat, dimana manfaat ini dapat terealisasi jika hutan terjamin keberadaannya, sehingga dapat berguna secara maksimal. Manfaat yang didapat dari hutan yaitu hasil hutan kayu dan hasil hutan non kayu. Manfaat tidak langsung dari hutan yaitu sebagai pengatur tata air, menciptakan kualitas udara yang bersih, dan sebagai penyerap emisi karbondioksida (CO2) sehingga dapat meredam pemanasan global (Asdak, 1995).

Selain mempunyai manfaat bagi kehidupan, hutan juga memiliki banyak manfaat salah satunya manfaat dalam bidang ekonomi. Kegunaan hutan dilihat dari sisi ekonomi,

\section{JIAKES}

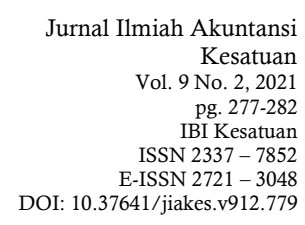
Kesatuan Vol. 9 No. 2, 2021 pg. $277-282$
IBI Kesatuan IBI Kesatuan
ISSN $2337-7852$ ISSN $2337-7852$
E-ISSN $2721-3048$ DOI: $10.37641 /$ jiakes.v912.779 
Analysis of Cost, Revenue and R/C Ratio

\section{8}

hutan berfungsi pada pengadaan lapangan pekerjaan dan sumber penghasilan bagi masyarakat. Hutan juga berguna sebagai penggerak sektor perekonomian dan memberikan nilai tambah. (Awang, 2002).

Fungsi hutan dalam perekonomian dapat dilihat dari kenaikkan Produk Domestik Bruto (PDB) sektor kehutanan. Data peningkatan PDB sektor kehutanan dapat dilihat pada tabel di bawah ini :

Tabel 1. Produk Domestik Bruto untuk sektor kehutanan atas dasar harga berlaku Tahun 2014-2018

\begin{tabular}{ccc}
\hline No & Tahun & PDB Sektor Kehutanan (dalam Milyar Rupiah) \\
\hline 1 & 2014 & 74,618 \\
\hline 2 & 2015 & 82,322 \\
\hline 3 & 2016 & 87,542 \\
\hline 4 & 2017 & 91,609 \\
\hline 5 & 2018 & 97,397 \\
\hline
\end{tabular}

Sumber: Badan Pusat Statistik, 2019

Pada tabel. 1 terlihat bahwa PDB sektor kehutanan pada tahun 2014-2018 mengalami kenaikan. Kenaikan terbesar terjadi pada tahun 2015 dengan perubahan sebesar Rp 7,704 milyar dari PDB tahun sebelumnya.

Peran sektor kehutanan terhadap Produk Domestik Bruto berupa hasil hutan kayu dan hasil hutan non kayu..Produksi kayu hutan di Provinsi Jawa Barat menurut jenis produksi per meter kubik $\left(\mathrm{m}^{3}\right)$ adalah sebagai berikut:

Tabel 2. Produksi Kayu Hutan di Provinsi Jawa Barat Tahun 2015-2019

\begin{tabular}{crrr}
\hline Tahun Produksi & \multicolumn{3}{c}{ Produksi Kayu Hutan Menurut Jenis Produksi $\left(\mathrm{m}^{3}\right)$} \\
\cline { 2 - 4 } & \multicolumn{1}{c}{ Kayu Bulat } & Kayu Gergajian & \multicolumn{1}{c}{ Kayu Lapis } \\
\hline 2015 & 1827085,50 & 1285852,86 & 38767,66 \\
\hline 2016 & 1212978,40 & 1453270,64 & 88767,66 \\
\hline 2017 & 2017497,26 & 11206566,27 & 88813,06 \\
\hline 2018 & 1397521,57 & 970073,01 & 87750,13 \\
\hline 2019 & 2421288,07 & 1534950,65 & 309248,30 \\
\hline
\end{tabular}

Sumber: jabar.bps.go.id

Dari data terlihat bahwa produksi kayu hutan di Provinsi Jawa Barat terdiri dari kayu bulat, kayu gergajian dan kayu lapis. Produksi kayu bulat lebih mendominasi dari dua jenis produksi kayu lainnya. Produksi kayu bulat dapat dikembangkan menjadi usaha kayu yang dapat diolah yang terus dilakukan karena perannya yang signifikan dalam meningkatkan ekonomi negara terutama pada masa pandemi seperti saat ini. Seperti diungkapkan oleh perwakilan dari Asosiasi Industri Permebelan dan Kerajinan Indonesia (Asmindo) yang dikutip dari www.bisnis.com menilai persoalan Covid-19 yang sudah masuk ke berbagai negara termasuk Indonesia, tidak mempengaruhi penjualan hasil kayu olahan dari Indonesia. Bahkan Asmindo menilai wabah tersebut membawa manfaat karena persaingan dari negara lain menurun. Oleh karena itu kebutuhan akan kayu khususnya kayu jati di Indonesia terus meningkat. Sehingga usaha kayu jati dinilai masih menguntungkan pada saat ini.

Kayu trubusan jati adalah pohon jati yang dibiarkan tumbuh sendiri selama bertahun tahun dan tanpa pemeliharaan khusus membuat pohon jati yang tumbuh memiliki kualitas dan besaran yang berbeda-beda sehingga sulit untuk menentukan keuntungan yang akan dihasilkan dari pohon jati tersebut karena hanya pohon jati yang memiliki kriteria tertentu yang dapat dihargai dengan nilai jual yang optimal.

Beberapa studi empiris yang menunjukkan bahwa untuk mengetahui suatu usaha menguntungkan atau tidak salah satunya dengan melakukan analisis biaya, pendapatan dan R/C ratio, diantaranya adalah hasil penelitian menurut Suriadi, dkk (2015), Rusnani, dkk (2016) dan Fatty (2015) menunjukkan hasil penelitian bahwa dengan menggunakan analisis biaya dan pendapatan dapat diketahui tingkat keuntungan usaha yang dijalankan. Penelitian Indriyani, dkk (2017) memperlihatkan bahwa biaya yang dialokasikan lebih rendah dari pendapatan yang diterima sehingga menghasilkan nilai 
$\mathrm{R} / \mathrm{C}$ ratio lebih dari satu maka usaha yang dijalankan dinilai menguntungkan dan layak dijalankan.

Tujuan penelitian ini yaitu untuk mengetahui: (1) Bagaimana analisis biaya usaha kayu trubusan JUN ? (2) Berapakah pendapatan yang akan didapatkan oleh Universitas Nusa Bangsa dari hasil penjualan kayu JUN ? (3) Berapakah nilai R/C ratio yang dihasilkan dari usaha kayu trubusan JUN ?

Menurut Mulyadi (2015:8) biaya adalah pengorbanan sumber ekonomi yang telah terjadi atau yang kemungkinan akan terjadi untuk tujuan tertentu dan menjadi informasi yang akurat dan sangat diperlukan untuk menghasilkan suatu keputusan yang tepat. Menurut Carter (2014:30) biaya adalah sebuah nilai tukar, sesuatu yang dikeluarkan atau dikorbankan yang dilakukan untuk menjamin perolehan manfaat atau hasil. Menurut Lestari (2017:14), objek biaya (cost object) adalah sesuatu yang diukur biayanya dan dibebankan. Sesuatu yang dimaksud dapat berbentuk produk, pelanggan, departemen, proyek, aktivitas dan sebagainya. Menurut Jhingan (2016: 31), pendapatan adalah penghasilan berupa uang selama periode waktu tertentu yang menyebabkan bertambahnya kemampuan seseorang. Menurut Soekartawi (2016), untuk mengetahui sebuah usaha layak atau tidak dijalankan maka digunakan analisis $\mathrm{R} / \mathrm{C}$ ratio yaitu rasio dari perbandingan antara total biaya dengan total pendapatan. Jika nilainya lebih dari satu maka usaha layak dijalankan.

\section{METODE PENELITIAN}

Penelitian ini menggunakan metode deskriptif kuantitatif. Data yang digunakan adalah data sekunder yang diperoleh dari pengelola Kebun Percobaan Universitas Nusa Bangsa. Data yang analisis adalah data biaya, data jumlah pohon dan data pendapatan penjualan hasil kayu trubusan Jati Unggul Nasional yang diolah secara kuantitatif menggunakan perhitungan analisis biaya dan pendapatan.

\section{HASIL DAN PEMBAHASAN}

\section{Sejarah JUN di Kebun Percobaan UNB}

Kebun percobaan Universitas Nusa Bangsa adalah kebun percobaan yang dimiliki oleh Universitas Nusa Bangsa dengan luas 11 Hektar yang peruntukkannya sebagai lahan percobaan untuk praktek perkuliahan mahasiswa di Universitas Nusa Bangsa yang terletak di Desa Cogreg. Pada tahun 2007 Universitas Nusa Bangsa melakukan kerjasama dengan Koperasi Perumahan Wanabakti Nusantara (KPWN) untuk budidaya tanaman Jati Unggul Nusantara (JUN) di kebun percobaan Cogreg. Unit bagi hasil KPWN merupakan lembaga usaha di bawah binaan Departemen Kehutanan yang mendukung program pembangunan kehutanan sebagai lembaga fasilitator. Peranan KPWN adalah mendukung pengembangan sumber daya hutan baru untuk meningkatkan penyediaan bahan baku industri (Humaira, et.al, 2013).

Awal penanaman JUN di kebun percobaan Cogreg dilaksanakan pada bulan Februari Tahun 2007 di lahan seluas 7,5 Hektar. Pada akhir bulan Desember tahun 2007, penanaman JUN kembali dilakukan di lahan seluas 2 Hektar. Bibit JUN yang ditanam berasal dari stek pucuk. Pemanenan kayu JUN pertama kali dilakukan bulan Maret sampai dengan April tahun 2013. Penebangan tahun 2013 tersebut dilakukan pada JUN yang terdapat di luasan 7,5 Hektar, sedangkan JUN pada luasan 2 Hektar di tebang pada tahun 2015. Bekas tebangan JUN pada luasan 7,5 Hektar memunculkan trubusan sejak tahun 2013 sampai saat ini.

Penjarangan jati trubusan dilakukan enam bulan setelah penebangan. Setelah enam bulan, ada sekitar 10-15 tunas yang muncul di setiap tunggak bekas tebangan. Setelah itu satu, dua, tiga tunas terbaik yang berbatang lurus dan sehat disisakan untuk membentuk tegakan selanjutnya. Setelah tergakan berumur tiga tahun, evaluasi dan penjarangan dilakukan kembali.

Jarak tanam JUN di kebun percobaan Cogreg adalah 5 x $2 \mathrm{~m}$, dengan jarak $5 \mathrm{~m}$ antar pohon JUN memanjang sejajar dengan arah Utara-Selatan. Pemupukan JUN dilakukan
Analysis of Cost, Revenue and R/C Ratio 
Analysis of Cost, Revenue and R/C Ratio setelah trubusan berumur 18 bulan dipupuk dengan pupuk NPK 250 g per pohon dengan cara menaburnya di sekeliling tunggak dan memendamnya dengan tanah.

Sejak kerjasama Universitas Nusa Bangsa dengan KPWN berakhir pada tahun 2013, pohon JUN trubusan dibiarkan hidup di lahan kebun percobaan Universitas Nusa Bangsa tanpa pemeliharaan dan pohon JUN yang tumbuh pada tahun 2013 sebanyak 6082 pohon tetapi setelah dilakukan penghitungan sampai bulan Maret 2021 pohon yang hidup berjumlah 5.291 pohon. Pohon yang mengalami kematian berjumlah 791 pohon atau sekitar 13 persen dari 6082 pohon. Hal ini terjadi karena satu-satunya pemeliharaan yang dilakukan adalah hanya pemberian pupuk NPK dan setelah itu tidak dilakukan pemupukan kembali.

\section{Analisis Biaya Usaha Kayu Trubusan JUN}

Biaya usaha kayu trubusan JUN yang dikeluarkan adalah seluruh biaya yang dikeluarkan sejak trubusan JUN tumbuh yaitu pada tahun 2013 sampai saat ini. Biaya yang dikeluarkan dalam usaha trubusan JUN adalah hanya biaya pemupukan yaitu biaya pupuk per pohon dikali dengan jumlah pohon. Setelah itu tidak ada pengeluaran biaya lagi karena pohon JUN dibiarkan tumbuh tanpa pemeliharaan. Jumlah pohon JUN trubusan yang tumbuh di tahun 2013 adalah berjumlah 6082 pohon. Kebutuhan pupuk NPK per pohon adalah 250 gr di kali 6082 pohon yaitu membutuhkan sekitar 1,52 ton pupuk. Harga beli pupuk per kg adalah Rp. 2.700. Jadi biaya yang dikeluarkan oleh Universitas Nusa Bangsa selama usaha JUN adalah sebesar Rp. 4.105.350.

Komposisi biaya dalam usaha kayu trubusan JUN tidak sesuai dengan komposisi biaya yang ada di dalam teori ekonomi karena kondisi di lapangan memang menunjukkan komposisi biaya yang dikeluarkan hanya biaya variabel dan itu hanya biaya pemupukan saja tidak ada komponen biaya tetap. Sehingga biaya yang dikeluarkan relatif sedikit.

\section{Analisis Pendapatan Usaha Kayu Trubusan JUN}

Seluruh pendapatan usaha kayu trubusan JUN adalah seluruh penerimaan dari hasil penjualan kayu trubusan JUN. Untuk menganalisis pendapatan usaha kayu trubusan digunakan standar penjualan kayu menurut Koperasi Perumahan Wanabakti Nusantara (KPWN). Jumlah pohon kayu trubusan JUN yang hidup sampai dengan bulan maret tahun 2021 adalah berjumlah 5.291 pohon. Terjadi pengurangan jumlah pohon dikarenakan mengalami kematian sebesar 13 persen atau sejumlah 791 pohon. Untuk harga penualan, KPWN membagi harga penjualan kayu JUN berdasarkan diameter pohonnya. Adapun standar harga kayu jati berdasarkan KPWN adalah sebagai berikut:

Tabel 3. Standar harga kayu JUN menurut KPWN berdasarkan diameter kayu

\begin{tabular}{ccc}
\hline No. & Diameter Kayu JUN (per cm) & Harga \\
\hline 1. & $50 \mathrm{~cm}$ ke atas & Rp. 75.00 \\
2. & $30-49 \mathrm{~cm}$ & Rp. 35.000 \\
3. & $30 \mathrm{~cm}$ ke bawah & Rp. 15.000 \\
\hline
\end{tabular}

Sumber: KPWN, 2021.

Dari tabel 3, terlihat bahwa harga kayu trubusan JUN ditentukan oleh besarnya diameter per $\mathrm{cm}$. Kayu yang berdiameter $50 \mathrm{~cm}$ ke atas dihargai seharga Rp. 75.000, untuk kayu yang berdiameter 30-49 cm dihargai seharga Rp. 35.000 dan kayu dengan diameter $30 \mathrm{~cm}$ kebawah dihargai seharga Rp. 15.000. Harga tersebut adalah harga standar yang dipakai KPWN ketika akan membeli kayu. Jika menggunakan standar harga dari KPWN maka pendapatan dari usaha kayu JUN adalah sebagai berikut :

Tabel 4. Perhitungan pendapatan kayu trubusan JUN berdasarkan KPWN

\begin{tabular}{ccccl}
\hline No. & $\begin{array}{c}\text { Diameter Kayu JUN } \\
\text { (per cm) }\end{array}$ & Harga & $\begin{array}{c}\text { Jumlah Kayu } \\
\text { (pohon) }\end{array}$ & \multicolumn{1}{c}{$\begin{array}{c}\text { Jumlah } \\
\text { Pendapatan }\end{array}$} \\
\hline 1. & $50 \mathrm{~cm}$ ke atas & Rp. 75.000 & 2.645 & Rp. 198.375 .000 \\
2. & $30-49 \mathrm{~cm}$ & Rp. 35.000 & 2.238 & Rp. 78.330.000 \\
3. & $\begin{array}{c}\text { 30 cm ke bawah } \\
\text { Total }\end{array}$ & Rp. 15.000 & 407 & Rp. 6.105.000 \\
& & & & Rp. 282.810.000 \\
\hline
\end{tabular}

Sumber: Data diolah, 2021 
Dari tabel 4, terlihat bahwa kayu yang berdiameter $50 \mathrm{~cm}$ ke atas berjumlah 2.645 pohon dikalikan dengan harga jual per pohon yaitu seharga Rp. 75.000 menjadi Rp. 198.375.000. Untuk kayu dengan diameter $30-49 \mathrm{~cm}$ berjumlah 2.238 pohon dikalikan dengan harga jual per pohon yaitu seharga Rp. 35.000 menjadi Rp. 78.330.000. Kayu dengan diameter $30 \mathrm{~cm}$ ke bawah berjumlah 407 pohon dikalikan dengan harga jual pohon yaitu seharga Rp. 15.000 menjadi Rp. 6.105.000. Dari perhitungan pendapatan kayu JUN diperoleh jumlah total pendapatan adalah sebesar Rp. 282.810.000.

\section{Analisis Keuntungan Usaha Kayu Trubusan JUN}

Analisis keuntungan pada usaha kayu trubusan JUN dihitung dengan menggunakan perhitungan total pendapatan dikurangi dengan total biaya.

Tabel 5. Hasil perhitungan pendapatan usaha kayu trubusan JUN

\begin{tabular}{cll}
\hline No. & Uraian & \multicolumn{1}{c}{ Jumlah } \\
\hline 1. & Penerimaan & Rp. 282.810.000 \\
2. & Total Biaya & Rp. 4.105.350 \\
& Total Pendapatan & Rp. 278.704.650
\end{tabular}

Dari tabel 5, terlihat bahwa total pendapatan dari usaha kayu trubusan JUN di kebun percobaan UNB adalah sebesar Rp. 282.810.000 dikurangi dengan total biaya sebesar Rp. 4.105.350 didapat keuntungan sebesar Rp. 278.704.650. Dari perhitungan analisis keuntungan terlihat bahwa usaha kayu trubusan JUN yang dilakukan di kebun percobaan UNB menghasilkan keuntungan. Hal ini terjadi karena biaya yang dikeluarkan oleh UNB hanya biaya untuk pemupukan saja tanpa ada biaya lain seperti biaya pemeliharaan dan biaya tenaga kerja.

\section{Analisis Kelayakan Usaha Kayu Trubusan JUN}

Kelayakan usaha kayu trubusan JUN dapat diketahui dengan menghitung R/C ratio dari usaha kayu trubusan JUN. Berikut perhitungan kelayakan usaha kayu trubusan JUN

$$
\mathrm{R} / \mathrm{C} \text { ratio }=\frac{T R}{T C}=\frac{282.810 .000}{4.105 .350}=6,88
$$

Berdasarkan hasil diatas dapat diketahui bahwa dari perbandingan antara jumlah penerimaan dan total biaya (R/C ratio) usaha kayu trubusan JUN sebesar 6,88. Hasil R/C ratio tersebut menunjukkan bahwa setiap pengeluaran $\mathrm{Rp} .1$ dalam kegiatan usaha kayu trubusan JUN, maka akan memberikan penerimaan usaha kayu trubusan JUN sebesar 6,88 . Hasil R/C ratio usaha kayu trubusan JUN tersebut lebih besar dari satu, sehingga usaha kayu trubusan JUN yang dilakukan di kebun percobaan UNB menguntungkan.

Usaha kayu trubusan JUN banyak dilakukan di Indonesia, tetapi usaha yang jalankan setiap pengusaha akan mendapatkan nilai $\mathrm{R} / \mathrm{C}$ ratio yang berbeda. Hal tersebut disebabkan perbedaan total biaya yang alokasikan dan pendapatan yang dihasilkan dari usaha kayu trubusan JUN.

\section{PENUTUP}

Berdasarkan hasil analisis mengenai analisis biaya, pendapatan dan $\mathrm{R} / \mathrm{C}$ ratio maka dapat disimpulkan bahwa:

1. Besarnya biaya yang dikeluarkan usaha kayu trubusan JUN di Kebun Percobaan Universitas Nusa Bangsa adalah sebesar Rp. 4.105.350.

2. Besarnya pendapatan dari usaha kayu trubusan JUN di Kebun Percobaan Universitas Nusa Bangsa adalah sebesar Rp. 278.704.650.

3. Besarnya R/C ratio pada usaha kayu trubusan JUN di Kebun Percobaan Universitas Nusa Bangsa adalah sebesar 6,88 . Hasil $\mathrm{R} / \mathrm{C}$ ratio memperlihatkan bahwa setiap biaya yang dikeluarkan Rp. 1 dalam usaha kayu trubusan JUN, maka akan memberikan penerimaan usaha kayu trubusan JUN sebesar 6,88 . Hasil R/C ratio usaha kayu trubusan JUN tersebut lebih besar dari satu, sehingga usaha kayu trubusan JUN yang dilakukan di kebun percobaan UNB menguntungkan.

Analysis of Cost, Revenue and R/C Ratio 
Analysis of Cost, Revenue and R/C Ratio

\section{2}

DAFTAR PUSTAKA

Asdak, Chay. 1995. Hidrologi Pengolahan Daerah Aliran Sungai. Yogyakarta: Gadjah Mada University Press.

Awang, S.A. 1995. Hutan Rakyat, Sosial Ekonomi dan Pemasaran. Yogyakarta: BPFEYogyakarta.

Anwar, A.D. and Amyar, F., 2020. Analisis Faktor-Faktor Yang Mempengaruhi Kualitas Audit Internal Dalam Pengambilan Keputusan Laporan Keuangan Pada PT Damar Bandha Jaya Bogor. Jurnal Ilmiah Akuntansi Kesatuan, 8(1), pp.87-96.

Carter, William K dan Milton F. Usry. 2014. Akuntansi Biaya. Diterjemahkan oleh Krista. Buku 1. Edisi 14. Jakarta: Salemba Empat.

Fitria, A. and Munawar, A., 2021. Pengaruh Penggunaan Internet Banking, Mobile Banking Dan SMS Banking Terhadap Kepuasan Nasabah Bank BNI. Jurnal Informatika Kesatuan, 1(1), pp.41-50.

Indriyani, Desilia., Soetoro, Fitri Yunroh. 2017. Analisis Biaya, Pendapatan dan R/C pada Agroindustri Serundeng Kelapa (Studi Kasus Pada Perusahaan Serundeng Sari Ayam Cap Koki di Desa Saguling Kecamatan Baregbeg Kabupaten Ciamis). Jurnal Ilmiah Mahasiswa AGROINFO GALUH. Vol. 4, Nomor.1, September 2017.

Jhingan, M.L. 2016. Analisis Usaha Tani. Jakarta: UI-Press.

Lestari, Wiwik dan Dhyka Bagus Permana. 2017. Akuntansi Biaya dalam Perspektif Manajerial. Depok: Rajawali Press.

Mulyadi. 2015. Akuntansi Biaya. Yogyakarta: UPP STIM YKPN.

Patty, Zeth. 2015. Analisa Biaya dan Pendapatan Furniture Berbahan Kayu Kelapa di Kota Tobelo (Studi Kasus Pada CV. CSSdi Tobelo, Halmahera Utara). Jurnal Agroforestri. Vol. X, Nomor. 2 Juni 2015.

Rusnani, Fahrizal., Sudirman Muin. 2016. Analisa Biaya dan Pendapatan Industri Pengolahan Kayu di Kabupaten Kubu Raya. Jurnal Hutan Lestari, Vol. 4(4) : 6436482016.

Soekartawi. 2016. Analisis Usaha Tani. Jakarta: UI-Press.

Suriadi, Suriadi., Daniel Itta, Magdalena Yoesran. 2015. Analisis Biaya dan Pendapatan Serta Waktu Pengembalian Modal Usaha Hasil Hutan Bukan Kayu Berupa Tanaman Hias. Jurnal Hutan Tropis. Vol. 3, No. 32015. 